\title{
Nitrite Toxicity to Danio rerio: Effects of Chloride Concentrations during Acclimatization and in Toxicity Tests
}

\author{
V. PIŠTĚKOVÁ, E. VOSLÁŘOVÁ, Z. SVOBODOVÁ \\ Department of Public Veterinary Medicine and Toxicology \\ University of Veterinary and Pharmaceutical Sciences, Brno, Czech Republic \\ Received April 14, 2005 \\ Accepted August 30, 2005
}

\begin{abstract}
Pištěková V., E. Voslářová, Z. Svobodová: Nitrite Toxicity to Danio rerio: Effects of Chloride Concentrations during Acclimatization and in Toxicity Tests. Acta Vet. Brno 2005, 74: 435-440.

The aquarium fish Danio rerio is the most frequently used species of fish for toxicity tests. The aim of the present study was to determine $\mathrm{NO}_{2}^{-}$toxicity to $D$. rerio and to evaluate effects of chloride concentrations during acclimatization and in toxicity tests. The semistatic method according to OECD 203 was used in the tests. The $96 \mathrm{hLC} 50 \mathrm{NO}_{2}^{-}$value for D. rerio was $242.41 \pm 13.67 \mathrm{mg} \cdot 1^{-1}$ at $19 \mathrm{mg} \mathrm{Cl} \cdot \mathrm{l}^{-1}$ in diluting water. There was a significant increase in $96 \mathrm{hLC}^{2} 0 \mathrm{NO}_{2}^{-}$to $318.02 \pm 50.65$ $\mathrm{mg} \cdot \mathrm{l}^{-1}$ and $387.40 \pm 43.99 \mathrm{mg} \cdot \mathrm{l}^{-1}$ following an increase in $\mathrm{Cl}^{-}$concentration in diluting water to 50 $\mathrm{mg} \cdot \mathrm{l}^{-1}(p<0.05)$ and $100 \mathrm{mg} \cdot \mathrm{l}^{-1}(p<0.01)$, respectively. A logarithmical relationship between $96 \mathrm{hLC} 50 \mathrm{NO}_{2}^{-}$values and chloride concentrations in diluting water $\left(\mathrm{R}^{2}=0.733\right)$ was demonstrated. A significant increase in $96 \mathrm{hLC} 50 \mathrm{NO}_{2}^{-}$values was found in toxicity tests in $D$. rerio acclimatized to increased $\mathrm{Cl}^{-}$concentrations for 96 hours before the test. In these cases $96 \mathrm{hLC} 50 \mathrm{NO}_{2}^{-}$was 378.81 $\pm 27.20 \mathrm{mg} \cdot l^{-1}\left(50 \mathrm{mg} \cdot 1^{-1} \mathrm{Cl}^{-} ; p<0.05\right)$ and $484.04 \pm 46.34 \mathrm{mg} \cdot \mathrm{l}^{-1}\left(100 \mathrm{mg} \cdot \mathrm{l}^{-1} \mathrm{Cl}^{-} ; p<0.01\right)$. D. rerio belongs to fish species less sensitive to nitrites. Results of the study confirmed the protective effect of chlorides, particularly in fish adapted to higher chloride concentrations prior to the test.
\end{abstract}

Danio rerio, 96hLC50, $\mathrm{NO}_{2}$, cōmpetition between $\mathrm{NO}_{2}$ añd $\mathrm{Cl}^{-}$

Increased nitrite concentrations in water is one of frequent problems encountered in both aquariums and on fish farms. Products of fish metabolism and decaying remains of food and faeces are mainly sources of nitrites. The basic product of protein metabolism of freshwater fish is ammonia $\left(\mathrm{NH}_{3}\right)$, which is released from the respiratory tract to water. It is converted by nitrification to toxic nitrites and, finally, to nitrates, which are almost non-toxic to fish. In aquariums, fish are most frequently poisoned by nitrites that accumulate in the tank as a result of inadequate efficiency of biological filters (Adamsson et al. 1988; Etscheidt 2003).

Nitrite toxicity to fish varies considerably and depends on a large number of external and internal factors (species and age of fish, water quality) whose importance is continuously verified and re-assessed. Nitrite toxicity to fish has been studied at various levels, different authors have reached sometimes even contradictory conclusions, but no final explanation of the combined effect of individual internal and external factors has been put forward (Lew is and Morris 1986; Svobodová et al. 2005a). The generally deleterious effect of nitrites results from the fact that they may pass from the aquatic environment through the gills to the fish where they react with haemoglobin to produce methaemoglobin. In this way, its oxygen transport capacity is hampered and the fish may die of hypoxia or anoxia (W oo and Chiu 1997; Knudsen and Jensen 1997).

Breeding aquarium fish, and mainly their export, is at present a significant source of income for the economy of the Czech Republic. For that reason, ways to minimize the risk of fish mortalities or damage due to excessive nitrite concentrations in water-recirculating

Address for correspondence:

MVDr. Vladimíra Pištěková, Ph.D.

University of Veterinary and Pharmaceutical Sciences

Department of Public Veterinary Medicine and Toxicology

Palackého 1-3, 61242 Brno

Czech Republic

Phone: +420 541562776

E-mail: pistekovav@vfu.cz

http://www.vfu.cz/acta-vet/actavet.htm 
systems are being investigated: one of possible ways how to enhance fish tolerance to nitrites is to increase chloride concentrations in water (Craw ford and Allen 1977; Mazik et al. 1991; Atwood et al. 2001; Jensen 2003; Lin and Chen 2003; Dvořák 2004; Svobodová et al. 2005a). The effect of increased chloride levels in the environment may result in competitive inhibition of nitrite uptake through the gills and other integumental tissues and/or it could result in elevated plasma and body fluid chloride levels. The level of chloride in the plasma is significant because of the possible competition between nitrite and chloride for entry into the red blood cell. Dietary and environmental chloride levels would then protect against $\mathrm{Fe}^{2+}$ in haemoglobin oxidation by nitrite (Perrone and Meade 1977). Nitrite toxicity to fish decreases with increasing chloride concentrations (Craw ford and Allen 1977; Russo and Thurston 1977; Svobodová et al. 2005b).

Zebrafish (Danio rerio) are at present the species most frequently used for toxicity tests (OECD and ISO methodological guidelines). For that reason, we also used zebrafish in our study. The aim of the present study was to determine the acute nitrite toxicity level for $D$. rerio, and to examine acute nitrite toxicity at various chloride concentrations and acute nitrite toxicity to that species of fish after a brief acclimatization to elevated chloride concentrations.

\section{Materials and Methods}

Tests of acute toxicity were performed on aquarium fish Danio rerio (Cyprinus rerio (Hamilton 1822) according to „Catalog of Fishes 2004“) aged 2 - 3 months (25 - 35 mm body length). The procedure complied with OECD No. 203 Acute Toxicity Test on Fish - Semistatic Method guidelines. The fish were acclimatized for 96 hours to different chloride concentrations before 96-hour acute toxicity tests were performed. A total of 5 series of experiments with $\mathrm{NO}_{2}{ }^{-}$concentrations ranging from 67 to $633 \mathrm{mg} \cdot \mathrm{l}^{-1}$ and different chloride concentrations were made:

1. fish acclimatized for $96 \mathrm{~h}$ with $19 \mathrm{mg} \cdot \mathrm{l}^{-1} \mathrm{Cl}^{-}, \mathrm{Cl}^{-}$test concentration $19 \mathrm{mg} \cdot \mathrm{l}^{-1}$

2. fish acclimatized for $96 \mathrm{~h}$ with $19 \mathrm{mg} \cdot \mathrm{l}^{-1} \mathrm{Cl}^{-}, \mathrm{Cl}^{-}$test concentration $50 \mathrm{mg} \cdot \mathrm{l}^{-1}$

3. fish acclimatized for $96 \mathrm{~h}$ with $19 \mathrm{mg} \cdot \mathrm{l}^{-1} \mathrm{Cl}^{-}, \mathrm{Cl}^{-}$test concentration $100 \mathrm{mg} \cdot \mathrm{l}^{-1}$

4. fish acclimatized for $96 \mathrm{~h}$ with $50 \mathrm{mg} \cdot 1^{-1} \mathrm{Cl}^{-}, \mathrm{Cl}^{-}$test concentration $50 \mathrm{mg} \cdot \mathrm{l}^{-1}$

5. fish acclimatized for $96 \mathrm{~h}$ with $100 \mathrm{mg} \cdot \mathrm{l}^{-1} \mathrm{Cl}^{-}, \mathrm{Cl}^{-}$test concentration $100 \mathrm{mg} \cdot \mathrm{l}^{-1}$

In each test series, 5 tests of acute toxicity were made, with 10 fish used for each concentration and for the control group.

Basic physical and chemical indices of diluting water used in the acute toxicity test were as follows: $\mathrm{ANC}_{4.5}$ (acid neutralisation capacity) $1.15 \mathrm{mmol} \cdot \mathrm{l}^{-1}$; CODMn (chemical oxygen demand) $1.9 \mathrm{mg} \cdot 1^{-1}$; total ammonia 31.4 $\mathrm{mg} \cdot \mathrm{l}^{-1} ; \mathrm{NO}_{3}^{-} 19.1 \mathrm{mg} \cdot \mathrm{l}^{-1} ; \mathrm{PO}_{4}^{3-} 0.01 \mathrm{mg} \cdot \mathrm{l}^{-1}$; sum of $\mathrm{Ca}+\mathrm{Mg} 14 \mathrm{mg} \cdot \mathrm{l}^{-1}$. Water temperatures in the test ranged $23 \pm 1$ ${ }^{\circ} \mathrm{C}$, oxygen saturation of water was above $60 \%$ (ranging from 85 to $96 \%$ ), pH ranged from 8.04 to 8.66.

During the tests, the fish condition was checked at 24-hour intervals and the number of dead fish was recorded for different concentrations. No fish from control groups died during any of the tests. The results obtained (number of fish dying in individual test concentrations) were processed by the probit analysis (EKO-TOX 5.1 software) to determine the $96 \mathrm{hLC} 50 \mathrm{NO}_{2}^{-}$value. For statistical processing of results (basic statistics, correlations between LC50 $\mathrm{NO}_{2}{ }^{-}$and $\mathrm{Cl}^{-}$concentrations in diluting water, significance of differences between $96 \mathrm{hLC} 50$ values from individual test series), Unistat 5.1. software was used.

\section{Results}

The acute $\mathrm{NO}_{2}{ }^{-}$toxicity to $D$. rerio as expressed by the $96 \mathrm{hLC} 50$ value was $242.41 \pm 13.67$ $\mathrm{mg} \cdot \mathrm{l}^{-1}$. This result was obtained with chloride concentration naturally occurring in the diluting water used, i.e. $19 \mathrm{mg} \cdot \mathrm{l}^{-1}$. The $96 \mathrm{hLC} 50 \mathrm{NO}_{2}^{-}$values for $D$. rerio obtained in acute toxicity tests with different chloride concentrations in diluting water are given in Fig. 1. Significant differences in $96 \mathrm{hLC} 50 \mathrm{NO}_{2}^{-}$values were found between tests with chloride concentrations of 19 and $50 \mathrm{mg} \cdot \mathrm{l}^{-1}(p<0.05), 19$ and $100 \mathrm{mg} \cdot \mathrm{l}^{-1}(p<0.01)$ and 50 and 100 $\mathrm{mg} \cdot 1^{-1}(p<0.05)$. Statistical evaluation of $96 \mathrm{hLC} 50 \mathrm{NO}_{2}^{-}$values obtained in acute toxicity tests when diluting water with increasing chloride concentrations was used (19 - $\left.100 \mathrm{mg}^{-1} \mathrm{l}^{-1}\right)$ demonstrated a logarithmic relationship between 96hLC50 $\mathrm{NO}_{2}^{-}$and chloride concentrations in diluting water (Fig. 2). The resulting regression equation is $y=-15.26+$ $86.69^{*} \operatorname{Ln}(\mathrm{x})\left(\mathrm{R}^{2}=0.733\right)$, where $x$ is chloride concentrations in diluting water $\left(\mathrm{in} \mathrm{mg} \cdot \mathrm{l}^{-1} \mathrm{Cl}\right)$ and $y$ is the value of $96 \mathrm{hLC} 50$ (in $\mathrm{mg} \cdot \mathrm{l}^{-1} \mathrm{NO}_{2}^{-}$). 


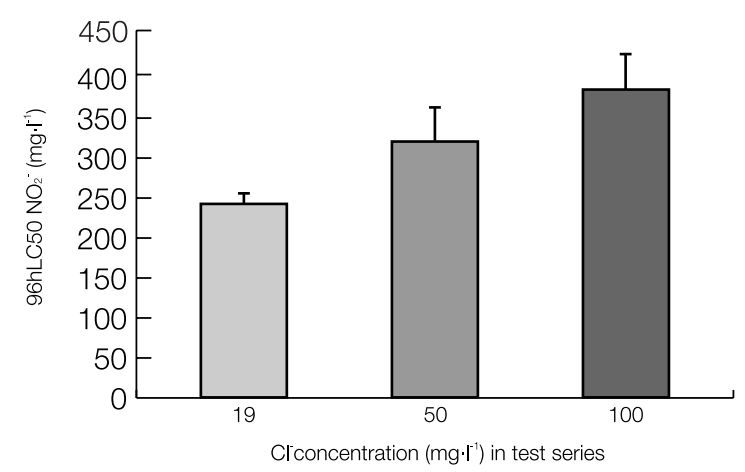

Fig. 1. Effects of higher chloride concentrations in diluting water to $96 \mathrm{hLC} 50 \mathrm{NO}_{2}{ }^{-}$in Danio rerio (test series 1,2 and 3)

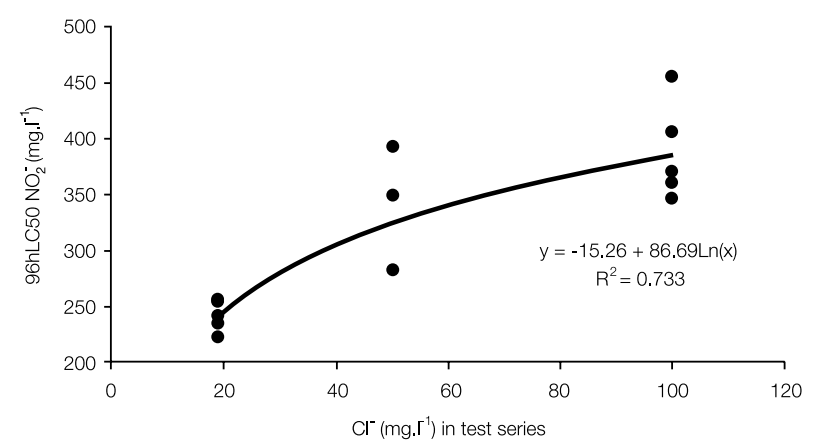

Fig. 2. Relationship between $96 \mathrm{hLC} 50 \mathrm{NO}_{2}{ }^{-}$values in Danio rerio and chloride concentrations in diluting water (test series 1,2 and 3)

An increase in $96 \mathrm{hLC} 50 \mathrm{NO}_{2}^{-}$was found in fish that were acclimatized in diluting water with higher $\mathrm{Cl}^{-}$concentrations (50 and $100 \mathrm{mg} \cdot 1^{-1}$ ) for 96 hours before the test start. Differences between $96 \mathrm{hLC} 0 \mathrm{NO}_{2}{ }^{-}$in fish acclimatized to increased chloride concentrations and fish acclimatized to diluting water containing chlorides at $19 \mathrm{mg} \cdot \mathrm{l}^{-1}$ concentration was statistically significant at $\mathrm{Cl}^{-}$concentrations of $50 \mathrm{mg} \cdot \mathrm{l}^{-1}(p<0.05)$ and $100 \mathrm{mg} \cdot \mathrm{l}^{-1}(p<0.01)$ (Fig. 3). The relation of $96 \mathrm{hLC} 50 \mathrm{NO}_{2}{ }^{-}$to chloride concentrations in diluting water following acclimatization to higher chloride concentrations (Fig. 4) is expressed by the regression equation $\mathrm{y}=-186.46+145.24 * \operatorname{Ln}(\mathrm{x})\left(\mathrm{R}^{2}=0.922\right)$, where $x$ is chloride concentration in diluting water (in $\mathrm{mg} \cdot \mathrm{l}^{-1} \mathrm{Cl}^{-}$) and $y$ is the value of 96hLC50 (in $\mathrm{mg} \cdot \mathrm{l}^{-1} \mathrm{NO}_{2}^{-}$).

\section{Discussion}

Considerable differences in fish species sensitivity to nitrite exposure have been reported by, e.g., Lewis and Morris (1986). They noticed that data from acute toxicity tests vary within a very wide range of results not just between different families of fish, but within families as well. At chloride concentration of $20 \mathrm{mg}^{-l^{-1}}$, they found $96 \mathrm{hLC} 50 \mathrm{NO}_{2}{ }^{-}$of 21.7 $\mathrm{mg} \cdot \mathrm{l}^{-1}$ for the rainbow trout, values over $207 \mathrm{mg} \cdot \mathrm{l}^{-1}$ for the common carp, $217 \mathrm{mg} \cdot \mathrm{l}^{-1}$ for Pimephales promelas and $355 \mathrm{mg} \cdot l^{-1}$ for Lepomis macrochirus. The $96 \mathrm{hLC} 50 \mathrm{NO}_{2}^{-}$value for $D$. rerio found in the present study $\left(242.41 \pm 13.67 \mathrm{mg} \cdot \cdot^{-1}\right)$ at $19 \mathrm{mg} \cdot \cdot^{-1}$ concentration of 


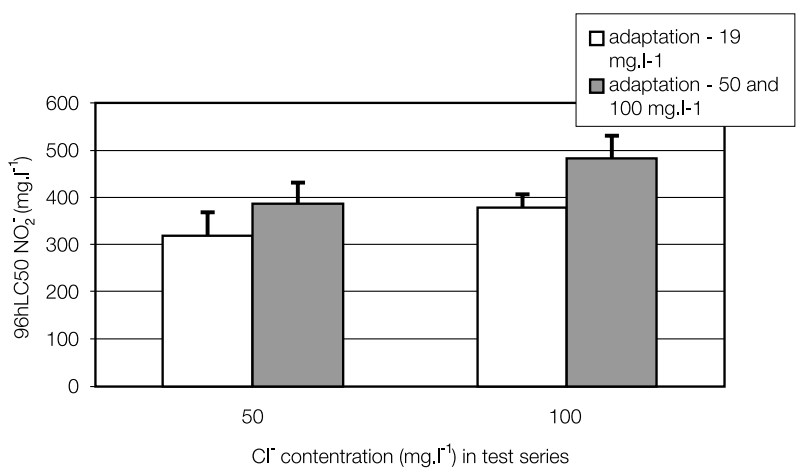

Fig. 3. Comparison between different $96 \mathrm{hLC} 50 \mathrm{NO}_{2}^{-}$values obtained in acute toxicity tests at different $\mathrm{Cl}^{-}$ concentrations on Danio rerio fish briefly acclimatized prior to tests to various chloride concentrations (comparison between results of series $2+4$ and $3+5$ )

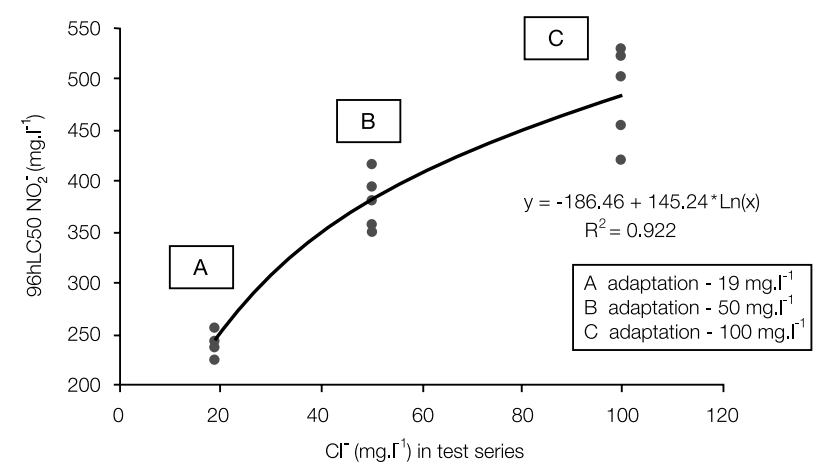

Fig. 4. Relationship between $96 \mathrm{hLC} 50 \mathrm{NO}_{2}^{-}$values and chloride concentrations in diluting water for Danio rerio fish acclimatized to $\mathrm{Cl}^{-}$concentrations $19,50,100 \mathrm{mg} \cdot l^{-1}$ before the $96 \mathrm{hLC} 50$ test (test series 1,4 and 5)

$\mathrm{Cl}^{-}$is comparable with the above results. In a study of the aquarium fish Poecilia reticulata, Kroupová et al. (2004) on the other hand found 96hLC50 $\mathrm{NO}_{2}{ }^{-}$lower by about one order of magnitude $\left(25 \mathrm{mg} \cdot \mathrm{l}^{-1}\right)$ as compared with results for $D$. rerio. Besides different species sensitivity, an important role in this case was probably played by a low chloride concentration in diluting water $\left(10 \mathrm{mg} \cdot \mathrm{l}^{-1}\right)$.

A significant effect of chloride concentrations in diluting water on $96 \mathrm{hLC} 50 \mathrm{NO}_{2}^{-}$was demonstrated in acute toxicity tests on Danio rerio. A logarithmic relationship between 96hLC50 $\mathrm{NO}_{2}^{-}$values and chloride concentrations in diluting water $\left(\mathrm{R}^{2}=0.733\right)$ was demonstrated. A linear relationship has been described in other fish species (Craw ford and Allen 1977; Russo and Thurston 1977; McConnell 1985; Lewis and Morris 1986; Kroupová et al. 2004).

Although increases in $96 \mathrm{hLC} 50 \mathrm{NO}_{2}{ }^{-}$as a result of increased chloride concentrations were statistically significant, the differences in values found for $D$. rerio were not as great as those found in other fish species. Crawford and Allen (1977) found that mortality of small chinook salmon in seawater occurred at nitrite concentrations 50 to 100 times higher than in fresh water. Kroupová et al. (2004) reported an increase of $96 \mathrm{hLC} 50 \mathrm{NO}_{2}{ }^{-}$in Poecilia reticulata from $25 \mathrm{mg} \cdot 1^{-1}\left(\mathrm{Cl}^{-} 10 \mathrm{mg} \cdot \mathrm{l}^{-1}\right)$ to $159 \mathrm{mg} \cdot \mathrm{l}^{-1}\left(\mathrm{Cl}^{-} 55 \mathrm{mg} \cdot \mathrm{l}^{-1}\right)$, i.e. more than six fold 
increase over the original value. In D. rerio, chloride concentration increase from $\mathrm{Cl}^{-} 19.0$ $\mathrm{mg} \cdot \mathrm{l}^{-1}$ to $50 \mathrm{mg} \cdot \mathrm{l}^{-1}$ in the environment resulted in only a $31 \%$ increase in $96 \mathrm{hLC} 50 \mathrm{NO}_{2}^{-}$ (from $242.41 \pm 13.67 \mathrm{mg} \cdot \mathrm{l}^{-1}$ to $318.02 \pm 50.65 \mathrm{mg} \cdot \mathrm{l}^{-1}$ ). It may be deduced that $D$. rerio is less sensitive to ambient nitrites than other species of fish. A greater protective effect of higher chloride concentrations might be therefore expected for this fish. For instance, Lew is and Morris (1986) concluded that the strength of the chloride effect is the greatest for the least sensitive species and the smallest for the most sensitive species. No such protective effect was confirmed in $D$. rerio.

It can be concluded from the computed regression equation of relationship between 96hLC50 $\mathrm{NO}_{2}^{-}$and chloride concentrations in diluting water that $1 \mathrm{mg} \cdot \mathrm{l}^{-1}$ increase in chloride concentration in diluting water results in the case of $D$. rerio in an increase of 8.27 $\mathrm{mg} \cdot \mathrm{l}^{-1}$ in $96 \mathrm{hLC5} 0 \mathrm{NO}_{2}^{-}$. Kroupová et al. (2004) reported an increase of $1.41 \mathrm{mg} \cdot \mathrm{l}^{-1}$ in $96 \mathrm{hLC} 0 \mathrm{NO}_{2}^{-}$in Poecilia reticulata. In their experiments on rainbow trout, Russo and Thurston (1977) found an increase of $0.95 \mathrm{mg} \cdot \mathrm{l}^{-1}$ in $96 \mathrm{hLC} 50 \mathrm{NO}_{2}^{-}$. In his study with Pimephales promelas, McConnell (1985) showed that an increase in chloride concentration in water by $1 \mathrm{mg} \cdot l^{-1}$ increased the $96 \mathrm{hLC} 50$ value by $6.57 \mathrm{mg} \cdot l^{-1} \mathrm{NO}_{2}^{-}$. The comparison of sensitivity of the above species of fish according to their $96 \mathrm{hLC} 50 \mathrm{NO}_{2}^{-}$ values, leads to a conclusion that the most sensitive species is the rainbow trout (Rus so and Thurston 1977), while Poecilia reticulata is less sensitive (Kroupová et al. 2004) and the least sensitive is Pimephales promelas (McConnell 1985). It can be concluded further that an increase in chloride concentration increases nitrite tolerance in the less sensitive species to a larger extent than in the more sensitive ones. The results obtained for $D$. rerio corroborate the above hypothesis because their $96 \mathrm{hLC} 50$ of $242.41 \pm 13.67 \mathrm{mg} \cdot \mathrm{l}^{-1}$ grew by $8.27 \mathrm{mg} \cdot \mathrm{l}^{-1}$ when chloride concentration in diluting water increased by $1 \mathrm{mg} \cdot \mathrm{l}^{-1}$.

In addition to the previously described positive effect of higher ambient chloride concentrations on nitrite toxicity to fish, our experiments also showed that this effect was greater in fish that had been acclimatized to higher chloride concentrations (50 and $100 \mathrm{mg} \cdot \mathrm{l}^{-1}$ ) prior to the toxicity tests. If fish were placed to diluting water with $\mathrm{Cl}^{-}$concentrations of 50 $\mathrm{mg} \cdot \mathrm{l}^{-1}$ and $100 \mathrm{mg} \cdot \mathrm{l}^{-1} 96$ hours prior to the beginning of tests, their $96 \mathrm{hLC} 50 \mathrm{NO}_{2}^{-}$values were $378.76 \pm 27.20 \mathrm{mg} \cdot \mathrm{l}^{-1}$ and $484.14 \pm 46.34 \mathrm{mg} \cdot \mathrm{l}^{-1}$, respectively. It can be concluded from the computed regression equation of the relation between 96hLC50 $\mathrm{NO}_{2}^{-}$and chloride concentrations in diluting water that an increase of $1 \mathrm{mg} \cdot \mathrm{l}^{-1}$ in chloride concentration results in an increase of $13.83 \mathrm{mg} \cdot \mathrm{l}^{-1}$ in $96 \mathrm{hLC} 50 \mathrm{NO}_{2}^{-}$in the case of $D$. rerio acclimatized to higher chloride concentrations. However, in the absence of acclimatization period, the increase in $96 \mathrm{hLC} 50 \mathrm{NO}_{2}^{-}$was only $8.27 \mathrm{mg} \cdot \mathrm{l}^{-1}$. This is probably related to changes in the microscopic structure of the gills occuring due to higher chloride concentrations during the acclimatization period. Svobodová et al. (2005b) noticed an increase in the number of eosinophilic chloride cells on the gills of carp exposed for 96 hours to diluting water containing $100 \mathrm{mg} \cdot \mathrm{l}^{-1}$ of chlorides.

\section{Toxicita dusitanů pro danio pruhované (Danio rerio): vliv koncentrace chloridů $\mathbf{v}$ průběhu adaptace a $\mathbf{v}$ testu toxicity}

Akvarijní ryba Danio rerio je nejpoužívanějším druhem ryb k testům toxicity. Cílem předkládané práce bylo stanovit toxicitu $\mathrm{NO}_{2}-$ pro $D$. rerio a zhodnotit efekt koncentrace chloridů $\mathrm{v}$ průběhu adaptace a při vlastním testu toxicity. Testy byly provedeny semistatickou metodou podle OECD 203. Zjištěná hodnota $96 \mathrm{hLC} 50 \mathrm{NO}_{2}$ - pro $D$. rerio byla $242,41 \pm 13,67 \mathrm{mg} \cdot \mathrm{l}^{-1}$ při koncentraci $\mathrm{Cl}^{-} \mathrm{v}$ ředicí vodě $19 \mathrm{mg} \cdot \mathrm{l}^{-1}$. K signifíkantnímu zvýšení hodnot 96hLC50 $\mathrm{NO}_{2}^{-}$došlo po zvýšení koncentrace $\mathrm{Cl}^{-} \mathrm{v}$ ředicí vodě v testu toxicity, a to na hodnotu $318 \pm 50,65 \mathrm{mg} \cdot \mathrm{l}^{-1}\left(50 \mathrm{mg} \cdot \mathrm{l}^{-1} \mathrm{Cl}^{-} ; p<0,05\right)$, resp. 387,40 $\pm 43,99 \mathrm{mg} \cdot \mathrm{l}^{-1}\left(100 \mathrm{mg} \cdot \mathrm{l}^{-1}\right.$ $\left.\mathrm{Cl}^{-} ; p<0,01\right)$. Byla prokázána logaritmická závislost hodnot $96 \mathrm{hLC} 50 \mathrm{NO}_{2}^{-}$na koncentraci 
chloridů v ředicí vodě $\left(\mathrm{R}^{2}=0,733\right)$. Signifikantní zvýšení hodnot $96 h \mathrm{LC} 50 \mathrm{NO}_{2}^{-}$bylo zjištěno v testech toxicity na $D$. rerio 96 hodin před testem adaptovaných na zvýšené koncentrace $\mathrm{Cl}^{-}$. V těchto případech byla hodnota $96 \mathrm{hLC} 50 \mathrm{NO}_{2}^{-} 378,81 \pm 27,20 \mathrm{mg} \cdot \mathrm{l}^{-1}$ $\left(50 \mathrm{mg} \cdot \mathrm{l}^{-1} \mathrm{Cl}^{-} ; p<0,05\right)$ a $484.04 \pm 46,34 \mathrm{mg} \cdot \mathrm{l}^{-1}\left(100 \mathrm{mg} \cdot \mathrm{l}^{-1} \mathrm{Cl}^{-} ; p<0,01\right)$. D. rerio patří mezi druhy ryb méně citlivé $\mathrm{k}$ dusitanům. $\mathrm{V}$ práci byl potvrzen ochranný vliv chloridů, a to především u ryb před testem adaptovaných ke zvýšeným koncentracím chloridů.

\section{Acknowledgements}

The work was carried out with the support of MSM Project No. 6215712402 "Veterinary Aspects of Foodstuff Safety and Quality".

\section{References}

ADAMSSON M, DAVE G, FOSBERG L, GUTERSTAM B 1998: Toxicity identification evaluation of ammonia, nitrite and heavy metals at the Stensund Wastewater Aquaculture plant. Water Sci Technol 38: 151-157

ATWOOD HL, FONTENOT QC, TOMASSO JR, ISELY JJ 2001: Toxicity of nitrite to Nile tilapia: effect of fish size and environmental chloride. N Amer J Aquac 63: 49-51

CRAWFORD RE, ALLEN GH 1977: Seawater inhibition of nitrite toxicity to chinook salmon. Trans Amer Fish Soc 106: 105-109

DVOŘÁK P 2004: Selected specificity of aquarium fish disease. Bulletin VÚRH Vodňany 40: 101-108

ETSCHEIDT J 2003: Nitrogen metabolites in ornamental and pond fishkeeping. Origin, elimination and veterinary relevance. Tierarztl Prax Ausgabe Kleintiere Heimtiere 31: 244-249

JENSEN FB 2003: Nitrite disrupts multiple physiological functions aquatic animals. Comp Biochem Physiol PT A 135: $9-24$

KNUDSEN PK, JENSEN FB 1997: Recovery from nitrite-induced methaemoglobinaemia and potassium balance disturbances in carp. Fish Physiol Biochem 16: 1-10

KROUPOVÁ H, MÁCHOVÁ J, SVOBODOVÁ Z, VALENTOVÁ O 2004: Acute toxicity of nitrite for Poecilia reticulata. Proceedings of International Conference „55 years of the Studies Programme of the fishery Specialization at Mendel University of Agriculture and Forestry in Brno, pp. 237-250.

LEWIS WM, MORRIS DP 1986: Toxicity of nitrite to fish - a review. Trans Amer Fish Soc 115: 183-195

LIN YC, CHEN JC 2003: Acute toxicity of nitrite on Litopenaeus vannamei (Boone) juveniles at different salinity levels. Aquaculture 224: 193-201

MAZIK PM, HINMAN ML, WINKELMANN DA, KLAINE SJ, SIMCO BA, PARKER NC 1991: Influence of nitrite and chloride concentrations on survival and hematological profiles of striped bass. Trans Amer Fish Soc 120: $247-254$

MCCONNELL R 1985: Toxicity of nitrite to the fathead minnow. Colorado Department of Health File Report, Denver

PERRONE SJ, MEADE TL 1977: Protective effect of chloride on nitrite toxicity to coho salmon (Oncorhynchus kisutch). J Fish Res Board Can 34: 486-492

RUSSO RC, THURSTON RV 1977: The acute toxicity of nitrite to fishes. In: TUBB RA (Ed.): Recent Advances in Fish Toxicity. US Environmental Protection Agency, Corvallis, pp. 118-131.

SVOBODOVÁ Z, MÁCHOVÁ J, POLESZCZUK G, HƯDA J, HAMÁČKOVÁ J, KROUPOVÁ H 2005a: Nitrite poisoning of fish in aquaculture facilities with water - recirculating systems. Acta Vet Brno 74: 129-137

SVOBODOVÁ Z, MÁCHOVÁ J, DRASTICHOVÁ, J., GROCH, L., LUSKOVÁ, H., POLESZCZUK G, VELÍŠEK, J., KROUPOVÁ, H. 2005b: Haematological and biochemical profile of carp blood following nitrite exposure at different concentrations of chloride. Aquac Res 36: in press

WOO NYS, CHIU SF 1997: Metabolic and osmoregulatory responses of the sea bass Lates calcarifer to nitrite exposure. Environ Toxic Water Qual 12: 257-264 